\title{
Editorial
}

Respiration

\section{Indacaterol/Glycopyrronium in Clinical Practice: The Italian Experience}

\author{
Mario Cazzola \\ Department of Experimental Medicine and Surgery, University of Rome Tor Vergata, Rome, Italy
}

Chronic obstructive pulmonary disease (COPD) has a very high prevalence worldwide and is associated with major morbidity and mortality [1]. The pharmacological therapy for COPD is aimed at controlling symptoms and reducing the number and frequency of acute exacerbations [2-4]. To this end, the 2017 Global Strategy for Diagnosis, Management and Prevention of COPD (GOLD 2017) guidelines suggest that prolonged bronchodilation with long-acting muscarinic antagonists (LAMA) and/or long-acting $\beta_{2}$-agonists (LABA), with or without inhaled corticosteroids (ICS), should be the elective strategy in COPD patients [4]. In more detail, LABA and LAMA should be preferred when administered in prefixed combinations, since this strategy allows maximizing their bronchodilation action through a synergistic effect on the relaxation of airway smooth muscles $[5,6]$.

Indacaterol and glycopyrronium have recently been introduced in the pharmacological armamentarium for COPD. The coadministration of these two bronchodilators in a fixed combination can improve bronchodilation by acting on different receptor types at submaximal doses
[7], thus reducing the risk of adverse effects [8-10]. This combination showed good efficacy in pivotal trials $[3,11-$ 13]. Studies evaluating the benefit of a indacaterol/glycopyrronium fixed-dose combination over consolidated therapies in a real-world setting are currently ongoing, but some positive preliminary results have already been disclosed [14]; in a pragmatic setting, the recently published CRYSTAL trial [15] has confirmed the benefits of switching directly to indacaterol/glycopyrronium from COPD standard of care.

In this supplement, we collected some interesting reports from Italian clinicians on indacaterol/glycopyrronium. In particular, we addressed the use of this therapy in patients with concomitant diseases such as cardiovascular issues and/or sleep apnea in elderly subjects, and we further investigated the role of indacaterol/glycopyrronium in the management of COPD. For a comprehensive evaluation of the benefits associated with this dual bronchodilator therapy, the report of these experiences of the clinical management of COPD patients is undoubtedly useful.

\section{KARGER}

(C) 2018 S. Karger AG, Basel

E-Mail karger@karger.com

www.karger.com/res
Mario Cazzola

Department of Experimental Medicine and Surgery

University of Rome Tor Vergata

Via Montpellier 1, IT-00133 Rome (Italy)

E-Mail mario.cazzola@uniroma2.it 


\section{References}

1 Wheaton AG, Cunningham TJ, Ford ES, Croft JB: Employment and activity limitations among adults with chronic obstructive pulmonary disease - United States, 2013. MMWR Morb Mortal Wkly Rep 2015;64: 289-295.

2 Baty F: Comorbidities and burden of COPD: a population based case-control study. PLoS One 2013;8:e63285.

3 Wedzicha JA, Banerji D, Chapman KR, Vestbo J, Roche N, Ayers RT, Thach C, Fogel R, Patalano F, Vogelmeier CF; FLAME Investigators: Indacaterol-glycopyrronium versus salmeterol-fluticasone for COPD. N Engl J Med 2016;374:2222-2234.

4 Vogelmeier CF, Criner GJ, Martinez FJ, Anzueto A, Barnes PJ, Bourbeau J, Celli BR, Chen R, Decramer M, Fabbri LM, Frith P, Halpin DM, López Varela MV, Nishimura M, Roche N, Rodriguez-Roisin R, Sin DD, Singh D, Stockley R, Vestbo J, Wedzicha JA, Agustí A: Global Strategy for the Diagnosis, Management, and Prevention of Chronic Obstructive Lung Disease 2017 Report. GOLD executive summary. Am J Respir Crit Care Med 2017; 195:557-582.

5 Calzetta L, Matera MG, Cazzola M: Pharmacological interaction between LABAs and LAMAs in the airways: optimizing synergy. Eur J Pharmacol. 2015;761:168-173.
6 Ficker JH: Role of dual bronchodilators in COPD: a review of the current evidence for indacaterol/glycopyrronium. Pulm Pharmacol Ther 2017;45:19-33.

7 Cazzola M, Calzetta L, Puxeddu E, Ora J, Facciolo F, Rogliani P, Matera MG: Pharmacological characterisation of the interaction between glycopyrronium bromide and indacaterol fumarate in human isolated bronchi, small airways and bronchial epithelial cells. Respir Res 2016;17:70.

8 O'Donnell DE, Casaburi R, Vincken W, Puente-Maestu L, Swales J, Lawrence D, Kramer B; INABLE 1 study group: Effect of indacaterol on exercise endurance and lung hyperinflation in COPD. Respir Med 2011;105:10301036.

9 Rossi A, Centanni S, Cerveri I, Gulotta C, Foresi A, Cazzola M, Brusasco V: Acute effects of indacaterol on lung hyperinflation in moderate COPD: a comparison with tiotropium. Respir Med 2012;106:84-90.

10 Cazzola M, Rogliani P: Comparative effectiveness of indacaterol/glycopyrronium in the treatment of chronic obstructive pulmonary disease. J Comp Eff Res 2017;6:627-636.

11 Vogelmeier CF, Bateman ED, Pallante J, Alagappan VK, D'Andrea P, Chen H, Banerji D: Efficacy and safety of once-daily QVA149 compared with twice-daily salmeterol-fluticasone in patients with chronic obstructive pulmonary disease (ILLUMINATE): a randomised, double-blind, parallel group study. Lancet Respir Med 2013;1:51-60.
12 Wedzicha JA, Decramer M, Ficker JH, Niewoehner DE, Sandström T, Taylor AF, D'Andrea P, Arrasate C, Chen H, Banerji D: Analysis of chronic obstructive pulmonary disease exacerbations with the dual bronchodilator QVA149 compared with glycopyrronium and tiotropium (SPARK): a randomised, double-blind, parallel-group study. Lancet Respir Med 2013;1:199-209.

13 Zhong N, Wang C, Zhou X, Zhang N, Humphries M, Wang L, Thach C, Patalano F, Banerji D; LANTERN Investigators: LANTERN: a randomized study of QVA149 versus salmeterol/fluticasone combination in patients with COPD. Int J Chron Obstruct Pulmon Dis 2015;10:1015-1026.

14 Kaplan A, Djandji M, Belle-Isle J, Anees S, McIvor A, Sampalis J, Mayers I: POWER: prospective cohort study for the real-life effectiveness evaluation of glycopyrronium with indacaterol combination in the management of COPD in Canada. Chest 2016; 150(suppl 4):835A.

15 Vogelmeier CF, et al: Efficacy and safety of direct switch to indacaterol/glycopyrronium in patients with moderate COPD: the CRYSTAL open-label randomised trial. Respir Res 2017;18:140 